\title{
Human growth hormone and insulin-like growth factor-I inhibit erythropoietin secretion from the kidneys of adult rats
}

\author{
Motoi Sohmiya and Yuzuru Kato \\ Department of Endocrinology, Metabolism and Hematological Oncology, Shimane University School of Medicine, Izumo 693-8501, Japan \\ (Requests for offprints should be addressed to M Sohmiya; Email: motoi@med.shimane-u.ac.jp)
}

\begin{abstract}
Growth hormone $(\mathrm{GH})$ and insulin-like growth factor-I (IGF-I) play important roles in erythropoiesis and erythropoietin (EPO) secretion. We examined the effects of $\mathrm{GH}$ and IGF-I on EPO production in adult rat kidney and liver in vivo and in vitro. Male Wistar rats aged 8-10 weeks were used. Recombinant human GH (hGH) was continuously infused $(20 \mu \mathrm{g} / \mathrm{kg}$ per h) subcutaneously for $48 \mathrm{~h}$ using a micro-osmotic infusion pump. Octreotide $(10 \mu \mathrm{g} / \mathrm{kg})$ was subcutaneously injected every $12 \mathrm{~h}$ beginning $12 \mathrm{~h}$ before the hGH treatment. GH increased plasma EPO levels earlier than it increased plasma IGF-I levels. At $24 \mathrm{~h}$, the IGF-I content in the liver and kidney was increased from $172 \cdot 8 \pm 14 \cdot 6$ to $232 \cdot 6 \pm 17 \cdot 8 \mathrm{ng} / \mathrm{g}$ tissue (means \pm S.E.) and from $53 \cdot 8 \pm 3 \cdot 1$ to $112 \cdot 8 \pm 7 \cdot 2 \mathrm{ng} / \mathrm{g}$ tissue, respectively. The EPO content in the liver was increased from
\end{abstract}

$7 \cdot 5 \pm 1 \cdot 2$ to $15 \cdot 1 \pm 1 \cdot 4 \mathrm{mIU} / \mathrm{g}$ tissue at $48 \mathrm{~h}$, whereas the $\mathrm{EPO}$ content in the kidney was decreased at 12, 24, and $48 \mathrm{~h}$ after the start of hGH treatment. When the kidneys were organ-cultured, hGH considerably decreased EPO levels in the culture medium in a dose-related manner. The addition of anti-hGH IgG blunted the GH-induced inhibition of EPO secretion from the kidneys. IGF-I also decreased EPO levels in the medium in a dose-related manner. The addition of anti-IGF-I IgG blunted the IGF-I-induced inhibition of EPO secretion from the kidneys, whereas the GH-induced inhibition of EPO secretion was not affected. These findings suggest that both hGH and IGF-I have direct inhibitory effects on EPO secretion from adult rat kidneys.

Journal of Endocrinology (2005) 184, 199-207

\section{Introduction}

The relationship between the endocrine system and hemopoiesis has been known for more than half a century (Watkinson et al. 1947, Gordon 1954, Crafts \& Meineke 1959, Jepson et al. 1968, Nagy \& Berczi 1989). Hypopituitarism is often accompanied by normochromic and normocytic anemia. Androgen and thyroid hormones are known to stimulate erythropoiesis (Alexanian 1969). Growth hormone $(\mathrm{GH})$ has a stimulatory effect on erythropoiesis (Fisher et al. 1964, Meineke \& Crafts 1968, Peschle et al. 1972, Golde et al. 1977). GH directly stimulated the proliferation of erythroid progenitor cells in vitro (Golde et al. 1977). Erythropoiesis was stimulated in rat bone marrow perfused with GH (Meineke \& Crafts 1968) and in nephrectomized and hypophysectomized rats (Fisher et al. 1964) in vivo. Hypoplastic bone marrow was restored by GH treatment, but not by adrenocorticotropic hormone, follicle stimulating hormone, luteinizing hormone, or thyroid-stimulating hormone (Jepson \& Lowenstein 1964, Nagy \& Berczi 1989). GH administration improved anemia in GH-deficient animals (Jepson \& McGarry 1972, Ten Have et al. 1997).
Erythropoietin (EPO), a potent regulator of erythropoiesis, is a glycoprotein with a molecular mass of 34000 Da. EPO secretion was strongly stimulated by hypoxia (Goldberg et al. 1989). EPO secretion is regulated endocrinologically. Thyroid hormones and adrenocortical hormone enhance EPO secretion (Peschle et al. 1978, Nagy \& Berczi 1989, Brenner et al. 1994, Fandrey et al. 1994). Although GH has a stimulatory effect on erythropoiesis, there have been few reports on the role of $\mathrm{GH}$ in EPO secretion. We previously reported that GH treatment increased plasma EPO levels in anemic patients with diabetic nephropathy (Sohmiya et al. 1998) and in patients with GH deficiency (Sohmiya \& Kato 2001). EPO is secreted from various organs depending on various conditions. EPO is secreted mainly from the peritubular endothelia and interstitial fibroblasts of renal tubules. It is also secreted partly from the liver in fetal rats (Bondurant \& Koury 1986, Clemons et al. 1986, Koury et al. 1988, 1989, Kurtz et al. 1989) and sheep (Zanjani et al. 1977, 1981), placenta (Davis et al. 2003), and astrocytes in the brain (Masuda et al. 1994). The liver is the primary site of EPO production in the fetus (Gruber et al. 1977, Zanjani et al. 1977, 1981), and extrarenal EPO production was 
increased in anemic rats (Erslev et al. 1980). In adult rats, EPO is secreted mainly from the kidney, suggesting that some mechanism switches EPO secretion from the liver to the kidney (Zanjani et al. 1981). This functional switching mechanism has yet to be fully elucidated. Fetal hypoxemia experiments showed that the EPO secretion from the placenta was increased by hypoxic stimuli (Davis et al. 2003). Physiological conditions might induce EPO secretion from the various organs. In particular, as the liver is the main target organ of $\mathrm{GH}, \mathrm{GH}$ administration affected EPO secretion from the liver. However, the roles of GH on EPO secretion and intervention of the kidney and liver in vivo and in vitro have not been elucidated fully. In the present study, we investigated the effects of $\mathrm{GH}$ and insulin-like growth factor-I (IGF-I) on EPO production in adult rat kidney and liver in vivo and in vitro.

\section{Materials and Methods}

\section{Reagents}

Recombinant human $\mathrm{GH}$ (rhGH) of the $22 \mathrm{kDa}$ form (rhGH-22k; Genotropin; Sumitomo Pharmaceutical Co., Tokyo, Japan) was kindly provided by the Sumitomo Pharmaceutical Co. Recombinant human IGF-I was purchased from GroPep Co. (Adelaide, SA, Australia). Octreotide (Sandostatin) was kindly provided by Sandoz Co. (Basel, Switzerland). Anti-hGH rabbit plasma and anti-IGF-I rabbit plasma were produced by multiple subcutaneous injection of hGH or recombinant IGF-I with Freund's complete adjuvant to rabbits. The antihGH IgG and anti-IGF-I IgG, both purified to the IgG fraction by Protein A column (Pharmacia, Uppsala, Sweden), were used in organ-culture experiments. Normal rabbit $\operatorname{IgG}$ was obtained by using the same method from normal rabbit plasma.

\section{Animal experiments}

Male Wistar rats (Japan Crea Co., Tokyo, Japan) aged 8-10 weeks were used throughout the experiments. The animals were maintained on a constant light/dark cycle (lights on 08:00-20:00 h) in a room controlled for temperature $\left(24 \pm 1{ }^{\circ} \mathrm{C}\right)$ and humidity $(50-60 \%)$. Tap water and laboratory chow pellets (Japan Crea Co.) were given ad libitum.

Octreotide $(10 \mu \mathrm{g} / \mathrm{kg})$ was injected subcutaneously every $12 \mathrm{~h}$ beginning $12 \mathrm{~h}$ before hGH administration. rhGH was infused subcutaneously for $48 \mathrm{~h}(20 \mu \mathrm{g} / \mathrm{kg}$ per h) using a micro-osmotic infusion pump (model 1003D; Alzet, Cupertino, CA, USA). Rats were divided into seven groups of eight rats each, for analysis at before $(0 \mathrm{~h})$ or after $(3,6,12,24$, or $48 \mathrm{~h})$ the start of GH infusion with octreotide treatment, or no treatment. At the end of each time point, rats were anesthetized with pentobarbital.
Each was placed on its back, and the abdominal cavity was opened. Blood samples were obtained from the abdominal aorta and centrifuged immediately. Plasma samples were stored at $-20{ }^{\circ} \mathrm{C}$ until assayed. The liver and kidney were perfused with $0 \cdot 1 \mathrm{M}$ ice-cold $\mathrm{PBS}, \mathrm{pH} 7 \cdot 4$. The kidneys were perfused via the abdominal aorta after the blood sampling. The liver was perfused via the hepatic portal vein using the once-through procedure (Waynforth \& Flecknell 1992). After the blood was completely displaced from the liver by massaging the organ gently between the fingers, the liver was excised and frozen at $-80{ }^{\circ} \mathrm{C}$ until extraction of EPO.

\section{Extraction of EPO}

EPO was extracted from the kidneys and liver using a modified extraction method (Sherwood \& Goldwasser 1978). The tissues of rat kidney and liver were homogenized with a Polytron homogenizer in $0.1 \mathrm{M}$ ice-cold PBS, $\mathrm{pH} 7 \cdot 4$, at a ratio of $5 \mathrm{ml}$ buffer to $1 \mathrm{~g}$ tissue. The homogenates were centrifuged at $15000 \mathrm{~g}$ for $30 \mathrm{~min}$, and the supernatants were applied to an ultracentrifugation device (Centricon 100; Amicon, Beverly, MA, USA) to remove the large proteins $(>100000 \mathrm{Da})$. The filtrated fractions were kept frozen at $-20{ }^{\circ} \mathrm{C}$ until assayed.

\section{Organ culture of the kidneys}

Organ culture of the kidney was performed by a modified method of Sherwood et al. (1972). Briefly, the kidneys were excised by an aseptic method and placed in ice-cold modified Tröwell's T8 medium supplemented with 10\% fetal calf serum, with $50 \mathrm{U} / \mathrm{ml}$ penicillin and $50 \mu \mathrm{g} / \mathrm{ml}$ streptomycin. The kidneys were cut into pieces (approximately $1 \mathrm{~mm}^{3}$ in volume), and between seven and 10 pieces were placed on a membrane filter $(0.65 \mu \mathrm{m}$; Durapore; Millipor Co., Bedford, MA, USA) in an organ-culture dish (Falcon; Becton Dickinson Co., Flanklin Lakes, NJ, USA). The level of the culture medium was adjusted so that only the membrane filter would be wetted. The kidneys were incubated with $1 \mathrm{ml}$ modified Tröwell's T8 medium in each culture dish. Kidney explants were cultured in serum-free Tröwell's T8 medium for up to 5 days. After preincubation for $24 \mathrm{~h}$, different concentrations of rhGH $\left(10^{-6}, 10^{-7}\right.$, and $\left.10^{-8} \mathrm{M}\right)$ and IGF-I $\left(10^{-6}, 10^{-7}\right.$, and $\left.10^{-8} \mathrm{M}\right)$ with or without anti-hGH rabbit IgG $(100 \mu \mathrm{g} / \mathrm{ml})$, anti-IGF-I rabbit $\operatorname{IgG}(100 \mu \mathrm{g} / \mathrm{ml})$, or normal rabbit $\operatorname{IgG}(100 \mu \mathrm{g} / \mathrm{ml})$ were added to the medium, and the explants were further incubated for $72 \mathrm{~h}$ in a humidified atmosphere of $95 \%$ air $/ 5 \% \mathrm{CO}_{2}$ at $37^{\circ} \mathrm{C}$. The medium was frozen immediately at $-20^{\circ} \mathrm{C}$ until assay. After the organ culture, the kidney fragment was fixed with formaldehyde and stained with hematoxylin/eosin, and the histological changes 

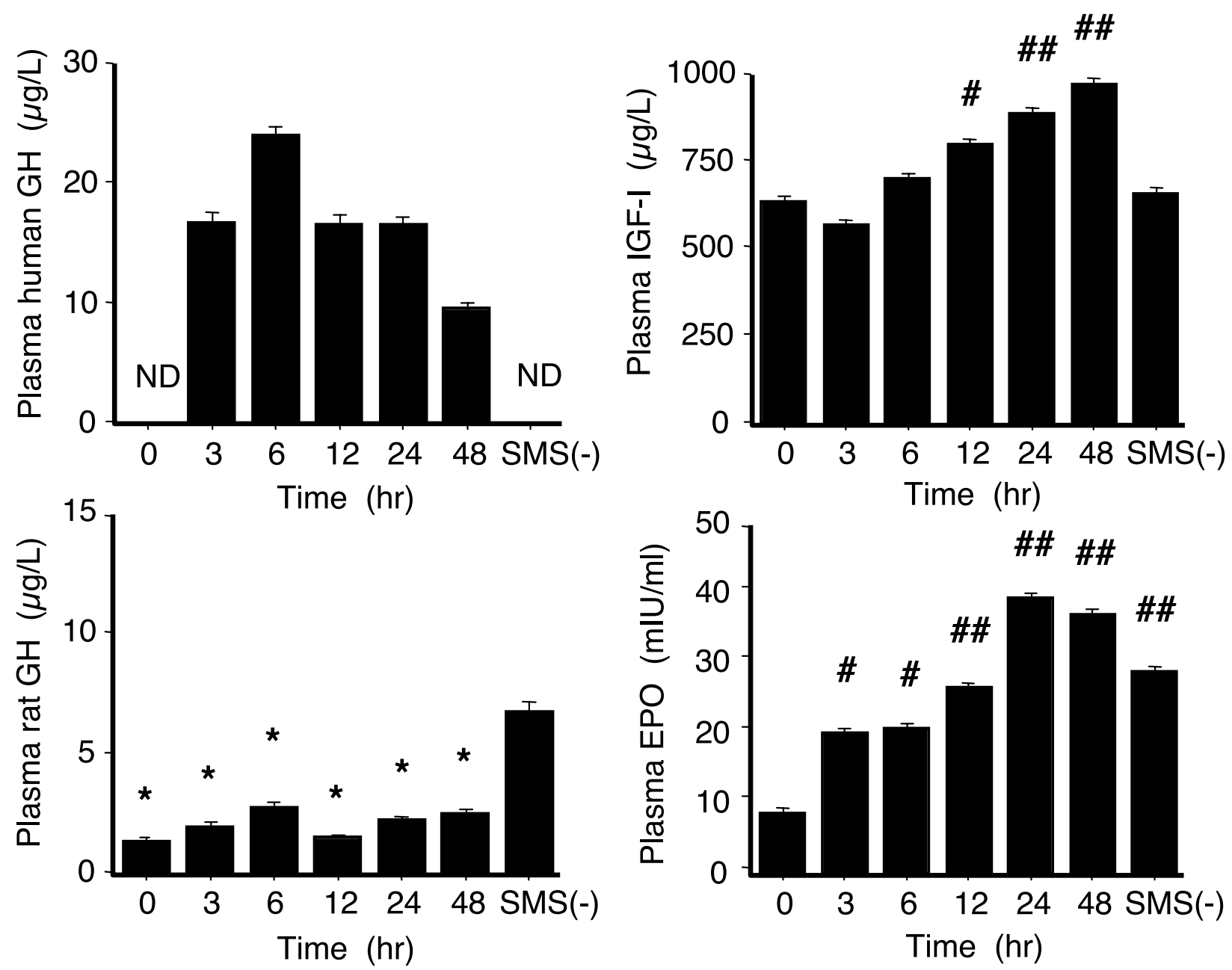

Figure 1 Effects of rhGH treatment on plasma hGH (left upper panel), rat GH (left lower panel), IGF-I (right upper panel), and EPO level (right lower panel) in rats pretreated with octreotide (SMS). ND, not detectable. SMS(-), not treated with octreotide. Means \pm S.E. are shown. ${ }^{*} P<0.005$ versus $S M S(-) ; \# P<0 \cdot 05$ versus time $0 ; \# \# P<0 \cdot 005$ versus time 0 .

were assessed. Little central necrosis was recognized in any of the fragments.

Assays

EPO levels in plasma, extracted solution, and culture medium were measured by a sensitive enzyme immunoassay (EIA) as previously described (Sohmiya \& Kato 2000). The minimal detectable quantity was $0 \cdot 15 \mathrm{mIU} / \mathrm{ml}$ using $100 \mu \mathrm{l}$. The intra- and inter-assay coefficients of variation were $6 \cdot 8 \%$ and $8 \cdot 2 \%$, respectively.

Plasma hGH levels were measured by highly sensitive EIA as previously described (Sohmiya \& Kato 1992, Sohmiya et al. 1993). Plasma rat GH levels were measured by a highly sensitive EIA as previously described (Sohmiya \& Kato 1994). There is no cross-reactivity of rat GH with $\mathrm{hGH}$ in the EIA. IGF-I levels in plasma and in the extracts of kidney and liver were measured by specific RIA after acid/ethanol extraction as described previously (Yamamoto et al. 1991).

\section{Statistical analysis}

The data are expressed as means \pm S.D. In the in vivo experiments, the experimental data were analyzed by repeated-measures ANOVA followed by Student's $t$-test. In the organ-culture experiments, the data were handled using Fisher's method as a post-hoc analysis. $P<0.05$ was considered significant.

\section{Results}

As shown in Fig. 1, plasma hGH levels increased from undetectable at $0 \mathrm{~h}$ to $23 \cdot 8 \pm 1 \cdot 8 \mu \mathrm{g} / 1$ (means \pm S.E.) at $6 \mathrm{~h}$ 

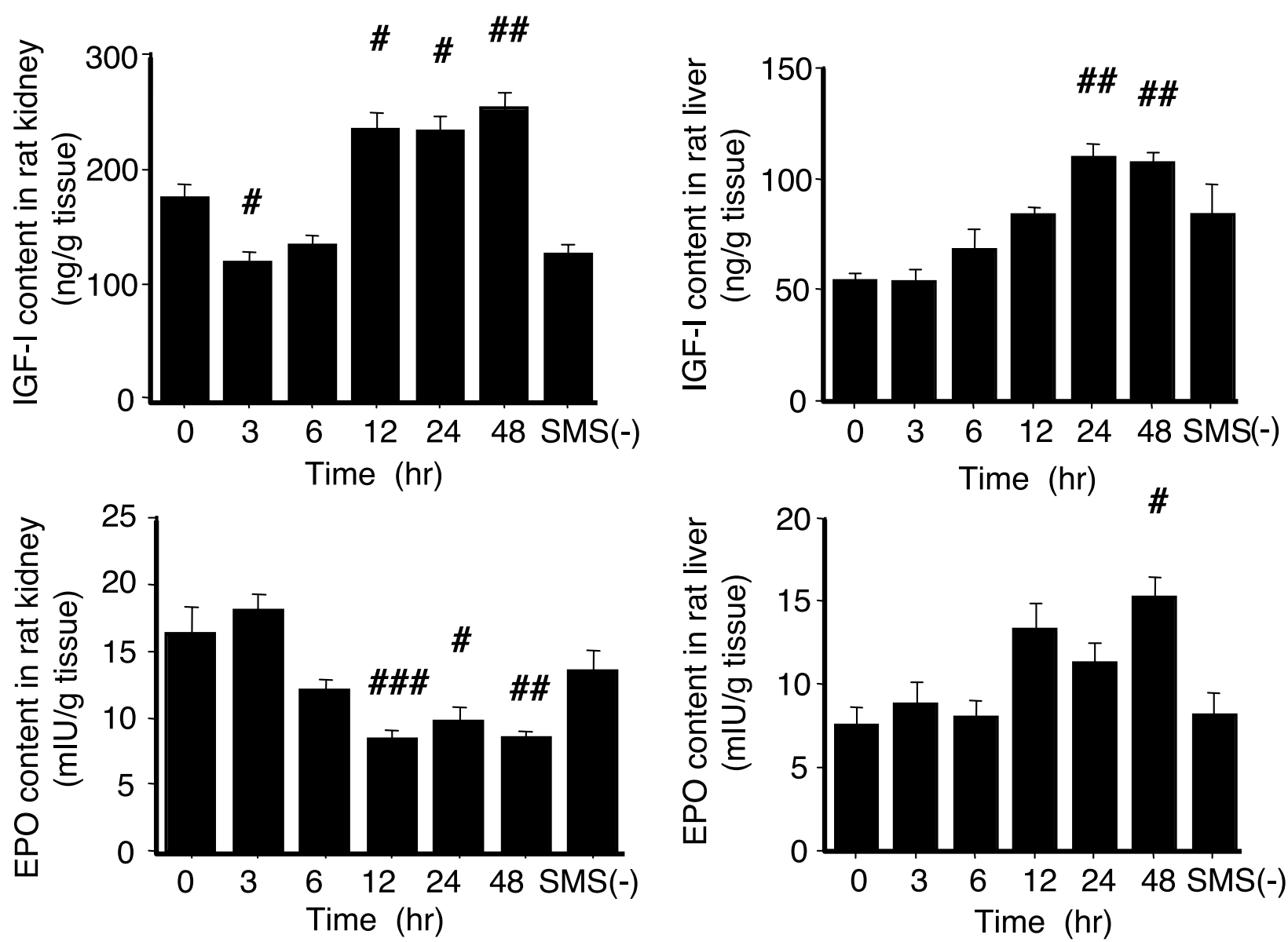

Figure 2 Effects of rhGH treatment on the content of IGF-I (upper panels) and EPO (lower panels) in liver (right-hand panels) and kidney (left-hand panels) pretreated with octreotide. SMS(-) shows not treated with octreotide. Means \pm S.E. are shown. \#P<0.05 versus time 0 ; $\# \# P<0 \cdot 01$ versus time $0 ; \# \# \# P<0 \cdot 005$ versus time 0 .

after the start of hGH infusion. Octreotide administration suppressed plasma rat GH levels. Plasma IGF-I levels increased from $625 \cdot 8 \pm 8 \cdot 7$ to $725 \pm 8 \cdot 7 \mu \mathrm{g} / \mathrm{l}$ at $12 \mathrm{~h}$ and peaked at $962 \cdot 0 \pm 12 \cdot 2 \mu \mathrm{g} / \mathrm{l}$ at $48 \mathrm{~h}$. The octreotide treatment made no difference in plasma IGF-I levels. Plasma EPO levels increased from $8 \cdot 0 \pm 1 \cdot 9$ to $12 \cdot 4 \pm 1 \cdot 8 \mathrm{IU} / 1$ at $3 \mathrm{~h}$ and peaked at $36 \cdot 5 \pm 1 \cdot 8 \mathrm{IU} / 1$ at $48 \mathrm{~h}$. Plasma EPO levels increased earlier than plasma IGF-I levels. There was a significant difference in plasma EPO levels with and without octreotide treatment.

The contents of IGF-I and EPO in the kidney and liver are shown in Fig. 2. The IGF-I content in the kidney increased from $172 \cdot 8 \pm 14 \cdot 6$ to $232 \cdot 6 \pm 17 \cdot 8 \mathrm{ng} / \mathrm{g}$ tissue at $12 \mathrm{~h}$. The IGF-I content in the liver increased from $53 \cdot 8 \pm 3 \cdot 1$ to $112 \cdot 8 \pm 7 \cdot 2 \mathrm{ng} / \mathrm{g}$ tissue at $24 \mathrm{~h}$. The EPO content in the liver increased from $7 \cdot 5 \pm 1 \cdot 2$ to $15 \cdot 1 \pm 1 \cdot 4$ $\mathrm{mIU} / \mathrm{g}$ tissue at $48 \mathrm{~h}$, whereas the EPO content in the kidney was decreased at 12,24 , and $48 \mathrm{~h}$ after the start of hGH treatment.
As shown in Fig. 3, hGH considerably decreased medium EPO levels in organ-cultured kidney in a doserelated manner $\left(10^{-7} \mathrm{M} \mathrm{GH}, 1 \cdot 22 \pm 0 \cdot 20\right.$, and $10^{-6} \mathrm{M}$ $\mathrm{GH}, 0.65 \pm 0 \cdot 18$, versus control, $1.81 \pm 0.13 \mathrm{mIU} / \mathrm{ml}$; $P<0.05$ and $P<0.005$, respectively). The addition of anti-hGH $\operatorname{IgG}(100 \mu \mathrm{g} / \mathrm{ml})$ blunted the GH-induced inhibition of EPO release from the organ-cultured kidneys, whereas normal rabbit IgG did not affect the $\mathrm{GH}$-induced inhibition of EPO release. As shown in Fig. 4, IGF-I also suppressed medium EPO levels in a dose-related manner $\left(10^{-7} \mathrm{M}\right.$ IGF-I, $1 \cdot 36 \pm 0 \cdot 07$, and $10^{-6}$ M IGF-I, $0 \cdot 99 \pm 0 \cdot 09$, versus control, $1 \cdot 85 \pm 0 \cdot 18$ $\mathrm{mIU} / \mathrm{ml} ; P<0 \cdot 01$ and $P<0 \cdot 0001$, respectively). The addition of anti-IGF-I IgG $(100 \mu \mathrm{g} / \mathrm{ml})$ blunted the IGF-Iinduced inhibition of EPO release from the organcultured kidneys. The addition of normal rabbit $\mathrm{IgG}$ did not affect the suppressive effect of IGF-I on EPO release. As shown in Fig. 5, we also found that the addition of anti-IGF-I $\operatorname{IgG}(100 \mu \mathrm{g} / \mathrm{ml})$ did not affect the 

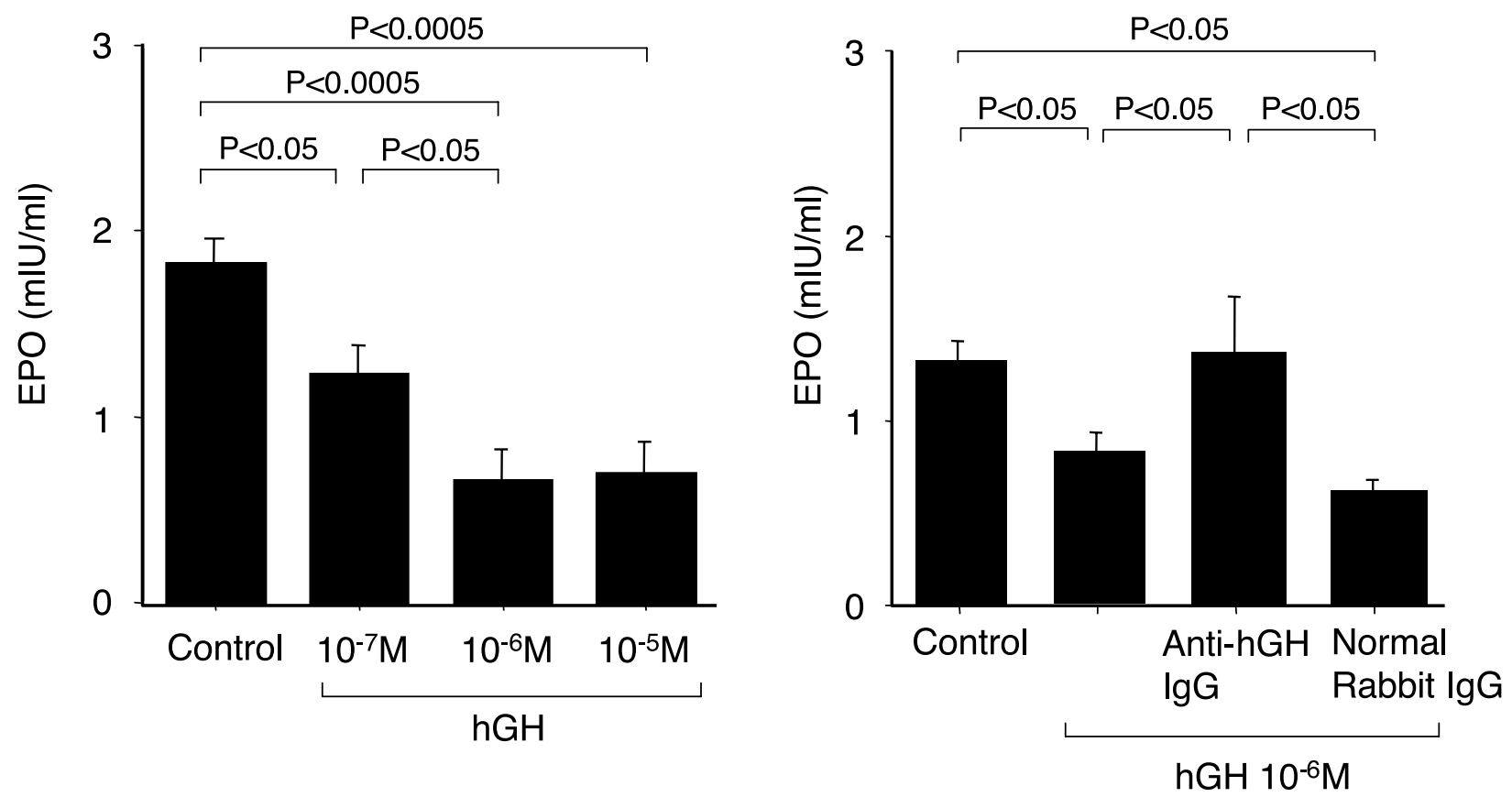

Figure 3 Effects of hGH on medium EPO levels in organ-cultured kidney. The EPO levels decreased by hGH in a dose-related manner $\left(10^{-7} \mathrm{M} \mathrm{hGH}, 1 \cdot 22 \pm 0 \cdot 20\right.$, and $10^{-6} \mathrm{M} \mathrm{hGH}, 0 \cdot 65 \pm 0 \cdot 18$, versus control, $1 \cdot 81 \pm 0 \cdot 13 \mathrm{mlU} / \mathrm{ml} ; P<0 \cdot 05$ and $P<0 \cdot 005$, respectively; left-hand panel). Addition of anti-hGH IgG $(100 \mu \mathrm{g} / \mathrm{ml})$ blunted the $\mathrm{GH}$-induced inhibition of EPO release from organ-cultured kidney. Addition of normal rabbit lgG did not affect the GH-induced inhibition of EPO release (right-hand panel). Means \pm S.E. are shown.

GH-induced inhibition of EPO secretion from the organcultured kidneys.

\section{Discussion}

EPO is a major humoral regulator of erythropoiesis. In the rat, it is secreted mainly from the endothelia and interstitial fibroblasts of renal tubules and partly from the liver (Kurtz et al. 1989, Koury et al. 1988, 1989). EPO secretion is controlled mainly by oxygen pressure (Koury et al. 1988, Eckardt et al. 1989). We previously reported that plasma EPO levels increased after the start of rhGH infusion in anemic patients with chronic renal failure (Sohmiya et al. 1998) and in adult patients with GH deficiency (Sohmiya \& Kato 2001). Human plasma EPO levels increased within $6 \mathrm{~h}$ after the start of rhGH administration, suggesting that $\mathrm{GH}$ directly stimulates EPO production. In the present study, rat plasma EPO levels were increased earlier than the increase of plasma IGF-I, suggesting that GH directly stimulates EPO secretion in vivo. On the other hand, it was reported that erythroid and myeloid progenitor precursor cells increased after $\mathrm{GH}$ replacement in adult patients with GH deficiency, whereas plasma EPO levels remained almost unchanged (Kotzmann et al. 1996). In the present study, rhGH and octreotide administration increased circulating EPO levels in adult rats. The octreotide administration dosage was sufficient to suppress endogenous rat
GH secretion. The decreased plasma EPO levels due to octreotide administration suggest that endogenous rat $\mathrm{GH}$ plays an important stimulatory role in EPO secretion in vivo.

EPO content decreased in the kidney, whereas it increased in the liver. These findings suggest that hGH's effects on EPO secretion differ depending on whether it is secreted from the kidney or the liver. The kidney could be the main site of EPO production in adult rats, and increased circulating EPO should originate from the kidney. However, our data suggest that the increased circulating EPO levels might originate from the liver instead. It is known that the liver is the major site of EPO production in the ovine fetus, whereas the kidney takes a major role in EPO production in adult sheep (Zanjani et al. 1981). In the neonatal rat, EPO was found to originate from the liver rather than the kidney, and hypoxic stimuli induced EPO production in both organs (Clemons et al. 1986). However, the results do not clarify the mechanism by which EPO is secreted from the liver. The present data suggest that GH suppresses EPO production from the kidney and that GH stimulates EPO secretion from the liver in a different manner than that from the kidney.

The organ-culture method was suitable for evaluating EPO secretion from kidney tissue (Sherwood et al. 1972), since EPO was secreted from some cell populations in the kidney, such as interstitial cells and peritubular endothelial cells. Sherwood et al. reported EPO production using organ culture of the rat kidney (Sherwood et al. 1972). 

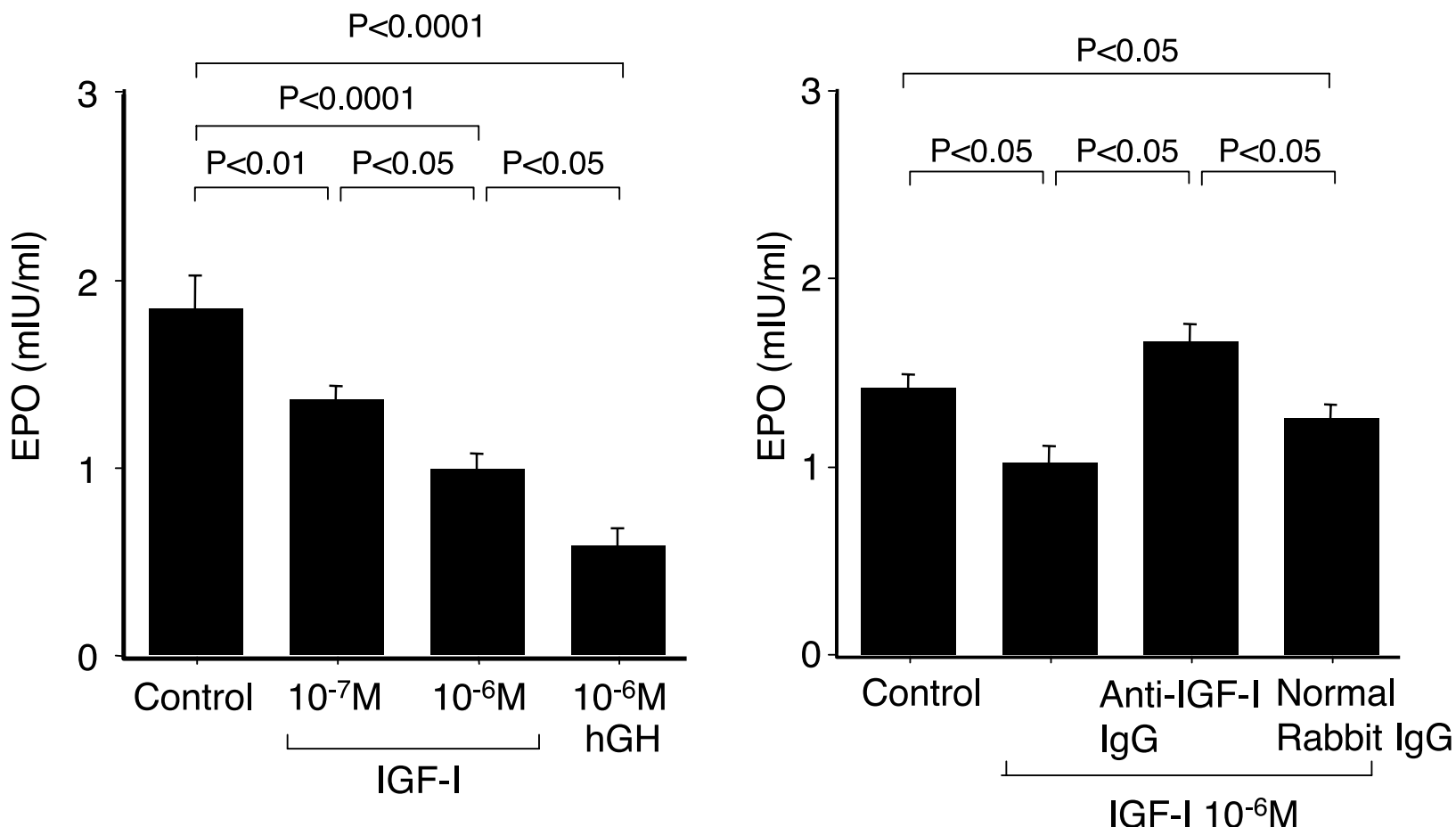

Figure 4 Effects of IGF-I on medium EPO levels in organ-cultured kidney. The EPO levels decreased by IGF-I in a dose-related manner $\left(10^{-7} \mathrm{M}\right.$ IGF-I, $1 \cdot 36 \pm 0 \cdot 07$, and $10^{-6} \mathrm{M}$ IGF-I, $0 \cdot 99 \pm 0 \cdot 09$, versus control, $1 \cdot 85 \pm 0 \cdot 18 \mathrm{mlU} / \mathrm{ml} ; P<0 \cdot 01$ and $P<0 \cdot 0001$, respectively; left-hand panel). Addition of anti-IGF-I IgG $(100 \mu \mathrm{g} / \mathrm{ml})$ blunted the IGF-I-induced inhibition of EPO secretion from organ-cultured kidney. Addition of normal rabbit IgG did not affect the suppressive effect of IGF-I on EPO secretion (right-hand panel). Means \pm S.E. are shown.

They used a bioassay to measure EPO levels. We measured medium EPO levels using a highly sensitive EIA with $0 \cdot 15 \mathrm{mIU} / \mathrm{ml}$ as the detectable quantity; this EIA was able to measure all of the EPO levels in the medium.

In the present study, hGH suppressed EPO release from organ-cultured kidneys into the medium in a dosedependent manner. Anti-IGF-I IgG administration with hGH could not inhibit the suppression of EPO secretion by $\mathrm{hGH}$, suggesting that $\mathrm{hGH}$ inhibited EPO secretion directly.

IGF-I stimulates erythropoiesis in vitro (Claustres et al. 1987, Merchav et al. 1988) and in vivo (Kurtz et al. 1988). However, there have been few reports on the relationship between IGF-I and EPO (Claustres et al. 1987, Kurtz et al. 1988, Merchav et al. 1988). IGF-I stimulates EPO secretion in patients with insulin resistance (Quin et al. 1994). On the other hand, it exerts a negative control function on oxygen-regulated EPO production in a human hepatoma cell line (Hep G2; Scholz et al. 1992). In the present study, IGF-I suppressed EPO secretion from the organ-cultured kidney. It decreased EPO content in the kidney, but increased it in the liver. IGF-I suppressed EPO secretion from the kidney organ culture, and the addition of anti-IGF-I IgG with IGF-I inhibited the suppression of EPO secretion, suggesting that IGF-I directly stimulated
EPO secretion from the kidney. IGF-I content was increased in the kidney and the liver. The minimum concentration of IGF-I that suppressed EPO secretion was $10^{-7} \mathrm{M}$. The effect was weaker than that of the same concentration of hGH. IGF-I might affect EPO secretion directly as well as by a paracrine mechanism. In the present study, the kidney fragments used in the organ culture consisted of heterogeneous cell populations. Therefore, the interaction between different cell types might be considered. Further investigation in prepared individual normal cells should be required.

The cellular mechanism of EPO secretion from the kidney is not fully elucidated. EPO is secreted mainly from interstitial cells and peritubular endothelial cells in normal kidneys of adult rats (Goldberg et al. 1989, Kurtz et al. 1989). Although there have been many perfusion experiments, there has been no report on culture experiments using interstitial cells and peritubular endothelial cells. This is because it is very complicated to prepare a primary culture of interstitial cells and endothelial cells from normal kidney tissue. Calcium regulates EPO secretion (Sherwood et al. 1987, Fisher 1988). An increase in intracellular calcium leads to the inhibition of EPO biosynthesis and/or of secretion, and a decrease in intracellular calcium increases EPO production in an established human renal cell 


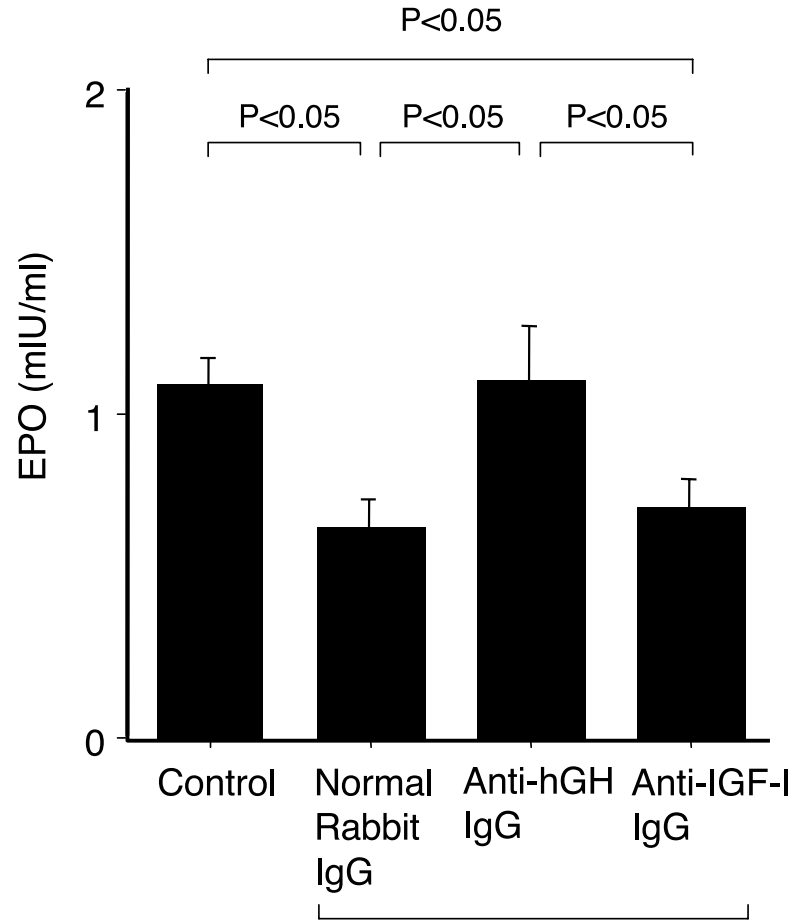

hGH $10^{-6} \mathrm{M}$

Figure 5 Effects of anti-IGF-I IgG on hGH-induced inhibition of EPO secretion. Addition of anti-IGF-I IgG $(100 \mu \mathrm{g} / \mathrm{ml})$ did not affect the $\mathrm{GH}$-induced inhibition of EPO secretion from organ-cultured kidney. Means \pm S.E. are shown.

carcinoma cell line (Sherwood et al. 1987). Primary culture experiments using a human renal cell carcinoma cell line indicate that a decreased $\mathrm{Ca}^{2+}$ concentration and the addition of a calcium antagonist induce EPO secretion in culture medium. Increased cAMP induces EPO secretion from an intracellular EPO-storage pool (Sherwood et al. 1987). Increased intracellular calcium activates a calcium/ calmodulin kinase and produces a phosphoprotein that inhibits EPO production and secretion (Fisher 1988). However, for a mechanism based on a carcinoma cell line, it is unknown whether or not the mechanism acts in normal cells and in different tissues from different organs.

Both $\mathrm{GH}$ receptor and GH-binding protein mRNAs are present in the liver, kidney, adrenal gland, heart, muscle, ovary, mammary gland, gastrointestinal tract, and adipose tissue (Tiong \& Herington 1991). IGF-I receptor is also present in many tissues such as liver, kidney, adipose tissue, muscle, neuron, cartilage, and others, and it plays a role in the regulation of metabolism, growth, and differentiation (De Meyts et al. 1994, Van Obberghen 1994). Therefore, the post-receptor pathway of GH and/or IGF-I might be related to EPO secretion. GH increases the intracellular free-calcium concentration in a variety of cell types (Schwartz \& Goodman 1990, Schwartz et al. 1992, Gaur et al. 1996, Udy et al. 1997, Zhu et al. 2001). An increase in intracellular calcium can be achieved by an influx of $\mathrm{Ca}^{2+}$ through voltage-dependent $\mathrm{Ca}^{2+}$ channels located in the plasma membrane or by mobilization of $\mathrm{Ca}^{2+}$ from intracellular stores (Cruzalegui \& Bading 2000). IGF-I also increases intracellular $\mathrm{Ca}^{2+}$ (Kojima et al. 1988, Poiraudeau et al. 1997). An increase in the intracellular calcium concentration decreased EPO secretion. Therefore, the increase in intracellular $\mathrm{Ca}^{2+}$ by $\mathrm{GH}$ and/or by IGF-I might at least partly affect the suppressive mechanism of EPO secretion.

$\mathrm{GH}$ and IGF-I levels were superphysiological levels in the organ-culture experiments. Stimulatory effects of GH and IGF-I on EPO secretion were not observed at concentrations lower than $10 \mu \mathrm{M}$ for GH and IGF-I. This might be attributed to the characteristics of the cell or tissue culture. Therefore, it was unknown whether EPO secretion from the kidney was suppressed by GH or IGF-I administration under physiological conditions in vivo or not.

Primate GH binds to both prolactin and GH receptors. Primate GH might partly have stimulatory effect on EPO secretion mediated by prolactin receptor. Our experiment using anti-GH antibody did not clarify whether the stimulatory effect of $\mathrm{GH}$ on EPO secretion was mediated by prolactin receptor and/or GH receptor. Further studies using GH receptor or prolactin receptor blocker are required.

The most interesting thing is the origin of increased circulating EPO level. In the next set of preliminary experiments, we found that GH stimulates EPO secretion from interstitial cells containing Kupffer cells, fibroblasts, and vascular endothelial cells whereas $\mathrm{GH}$ rather inhibits EPO release from parenchymal cells in the rat liver, indicating that an increase in plasma EPO levels after GH treatment might be derived from interstitial cells in the liver (data not shown).

In conclusion, the continuous subcutaneous infusion of hGH stimulated EPO secretion in rats. Plasma EPO levels were increased earlier than plasma IGF-I levels. The EPO content decreased in the kidney but increased in the liver, and EPO secretion decreased in organ-cultured kidneys. In organ culture of rat kidneys, EPO secretion was inhibited by the addition of hGH and IGF-I. The inhibitory effect of EPO secretion by hGH was not blunted by anti-IGF-I IgG. These findings suggest that both GH and IGF-I have direct inhibitory effects on EPO secretion from rat kidneys.

\section{Acknowledgments}

This work was supported in part by grants from the Ministry of Education, Science and Culture, Japan, the Ministry of Health and Welfare, Japan, the Growth Science Foundation, Japan, and the Foundation for Renal Anemia Therapy, Japan. We are indebted to Mrs Akiko 
Kawakami and Mrs Akiko Kanayama for their secretarial assistance. The authors declare that there is no conflict of interest that would prejudice the impartiality of this scientific work.

\section{References}

Alexanian R 1969 Erythropoietin and erythropoiesis in anemic man following androgen. Blood 33 564-572.

Bondurant MC \& Koury MJ 1986 Anemia induces accumulation of erythropoietin mRNA in the kidney and liver. Molecular Cell Biology 6 2731-2733.

Brenner B, Fandrey J \& Jelkmann W 1994 Serum immunoreactive erythropoietin in hyper- and hypothyroidism: clinical observations related to cell culture studies. European Journal of Haematology $\mathbf{5 3}$ 6-10.

Claustres M, Chatelain P \& Sultan C 1987 Insulin-like growth factor I stimulates human erythroid colony formation in vitro. Journal of Clinical Endocrinology and Metabolism 65 78-82.

Clemons GK, Fitzsimmons SL \& Pemanincor D 1986 Immunoreactive erythropoietin concentration in fetal and neonatal rats and the effects of hypoxia. Blood 68 892-899.

Crafts SG \& Meineke HA 1959 The anemia of hypophysectomized animals. Annals of New York Academy of Science 77 501-517.

Cruzalegui FH \& Bading H 2000 Calcium-regulated protein kinase cascades and their transcription factor targets. Cellular and Molecular Life Sciences 57 402-410.

Davis LE, Widness JA \& Brace RA 2003 Renal and placental secretion of erythropoietin during anemia or hypoxia in the ovine fetus. American Journal of Obstetrics and Gynecology 189 1764-1770.

De Meyts P, Wallach B, Christoffersen CT, Urso B, Gronskov K, Latus LJ, Yakushiji F, Ilondo MM \& Shymko RM 1994 The insulin-like growth factor-I receptor. Structure, ligand-binding mechanism and signal transduction. Hormone Research 42 152-169.

Eckardt K, Kurtz A, Scholz H \& Bauer C 1989 Regulation of erythropoietin formation in vivo. Contribution to Nephrology 76 33-38.

Erslev AJ, Caro J, Kansu E \& Silver R 1980 Renal and extrarenal erythropoietin production in anaemic rats. British Journal of Haematology 45 65-72.

Fandrey J, Pagel H, Frede S, Wolff M \& Jelkmann W 1994 Thyroid hormones enhance hypoxia-induced erythropoietin production in vitro. Experimental Hematology 22 272-277.

Fisher JW 1988 Pharmacologic modulation of erythropoietin production. Annual Review of Pharmacology and Toxicology 28 101-122.

Fisher JW, Roh BL, Couch C \& Nightingale WO 1964 Influence of cobalt, sheep erythropoietin and several hormones on erythropoiesis in bone marrows of isolated perfused hind limbs of dogs. Blood 23 87-98.

Gaur S, Yamaguchi H \& Goodman HM 1996 Growth hormone increases calcium uptake in rat fat cells by a mechanism dependent on protein kinase C. American Journal of Physiology Cell Physiology 270 C1485-C1492.

Goldberg MA, Imagawa S, Dunning PS \& Bunn HF 1989 Oxygen sensing and erythropoietin gene regulation. Contribution to Nephrology 70 39-56.

Golde DW, Bersch N \& Li CH 1977 Growth hormone: species-specific stimulation of erythropoiesis in vitro. Science 196 1112-1113.

Gordon AS 1954 Endocrine influences upon the formed elements of blood and blood forming organs. Recent Progress in Hormone Research 10 339-394.

Gruber DF, Zucali JR \& Mirand EA 1977 Identification of erythropoietin producing cells in fetal mouse liver cultures. Experimental Hematology 5 392-398.
Jepson JH \& Lowenstein L 1964 Effect of prolactin on erythropoiesis in the mouse. Blood 24 726-738.

Jepson JH \& McGarry EE 1972 Hemopoiesis in pituitary dwarfs treated with human growth hormone and testosterone. Blood 39 238-248.

Jepson JH, McGarry EE \& Lowenstein LL 1968 Erythropoietin excretion in a hypopituitary patient. Effects of testosterone and vasopressin. Archives of Internal Medicine 122 265-270.

Kojima I, Matsunaga H, Kurokawa K, Ogata E \& Nishimoto I 1988 Calcium influx: an intracellular message of the mitogenic action of insulin-like growth factor-I. Journal of Biological Chemistry 263 16561-16567.

Kotzmann H, Riedl M, Clodi M, Barnas U, Kaider A, Hocker P \& Luger A 1996 The influence of growth hormone substitution therapy on erythroid and myeloid progenitor cells and on peripheral blood cells in adult patients with growth hormone deficiency. European Journal of Clinical Investigation 26 1175-1181.

Koury ST, Bondurant MC \& Koury MJ 1988 Localization of erythropoietin synthesizing cells in murine kidneys by in situ hybridization. Blood 71 524-527.

Koury ST, Koury MJ, Bondurant MC, Caro J \& Graber SE 1989 Quantitation of erythropoietin-producing cells in kidneys of mice by in situ hybridization: correlation with hematocrit, renal erythropoietin mRNA, and serum erythropoietin concentration. Blood 74 645-651.

Kurtz A, Zapf J, Eckardt KU, Clemons G, Froesch ER \& Bauer C 1988 Insulin-like growth factor I stimulates erythropoiesis in hypophysectomized rats. PNAS 85 7825-7829.

Kurtz A, Eckardt KU, Neumann R, Kaissling B, Le Hir M \& Bauer C 1989 Site of erythropoietin formation. Contribution to Nephrology 76 14-23.

Masuda S, Okano M, Yamagishi K, Nagao M, Ueda M \& Sasaki R 1994 A novel site of erythropoietin production. Oxygen-dependent production in cultured rat astrocytes. Journal of Biological Chemistry 269 19488-19493.

Meineke HA \& Crafts RC 1968 Further observations on the mechanism by which androgens and growth hormone influence erythropoiesis. Annals of the New York Academy of Sciences 149 298-307.

Merchav S, Tatarsky I \& Hochberg Z 1988 Enhancement of erythropoiesis in vitro by human growth hormone is mediated by insulin-like growth factor I. British Journal of Haematology $\mathbf{7 0}$ 267-271.

Nagy E \& Berczi I 1989 Pituitary dependence of bone marrow function. British Journal of Haematology 71 457-462.

Peschle C, Rappaport IA, Sasso GF, Gordon AS \& Condorelli M 1972 Mechanism of growth hormone (GH) action on erythropoiesis. Endocrinology 91 511-517.

Peschle C, Rappaport IA, Magli MC, Marone G, Lettieri F, Cillo C \& Gordon AS 1978 Role of the hypophysis in erythropoietin production during hypoxia. Blood 51 1117-1124.

Poiraudeau S, Lieberherr M, Kergosie N \& Corvol MT 1997 Different mechanisms are involved in intracellular calcium increase by insulin-like growth factors 1 and 2 in articular chondrocytes: voltage-gated calcium channels, and/or phospholipase C coupled to a pertussis-sensitive G-protein. Journal of Cellular Biochemistry 64 414-422.

Quin J, Miell J, Smith K, Gordon D, Strachan J, Dick JB \& MacCuish AC 1994 Effect of insulin-like growth factor-I therapy on erythropoietin concentrations in extreme insulin resistance. Diabetologia 37439.

Scholz H, Baier W, Ratcliffe P, Eckardt K, Zapf J, Kurtz A \& Bauer C 1992 Insulin-like growth factors decrease oxygen-regulated erythropoietin production by human hepatoma cells (Hep G2). American Journal of Physiology Cell Physiology 263 C474-C479.

Schwartz Y \& Goodman HM 1990 Refractoriness to the insulin-like effects of growth hormone depends upon calcium. Endocrinology 127 $170-176$. 
Schwartz Y, Yamaguchi H \& Goodman HM 1992 Growth hormone increases intracellular free calcium in rat adipocytes: correlation with actions on carbohydrate metabolism. Endocrinology 131 772-778.

Sherwood JB \& Goldwasser E 1978 Extraction of erythropoietin from normal kidneys. Endocrinology 103 866-870.

Sherwood JB, Robinson SH, Bassan LR, Rosen S \& Gordon AS 1972 Production of erythropoietin by organ cultures of rat kidney. Blood $40189-197$.

Sherwood JB, Burns ER \& Shouval D 1987 Stimulation by cAMP of erythropoietin secretion by an established human renal carcinoma cell line. Blood 69 1053-1057.

Sohmiya M \& Kato Y 1992 Renal clearance, metabolic clearance rate and half life of human growth hormone in young and aged subjects. Journal of Clinical Endocrinology and Metabolism 75 1487-1490.

Sohmiya M \& Kato Y 1994 A highly sensitive enzyme immunoassay of rat growth hormone $(\mathrm{GH})$ and the inhibitory effect of $\mathrm{GH}$ on GH secretion in the rat. Biomedical Research 5 207-214.

Sohmiya M \& Kato Y 2000 Molecular and electrical heterogeneity of circulating human erythropoietin measured by sensitive enzyme immunoassay. European Journal of Clinical Investigation 30 344-349.

Sohmiya M \& Kato Y 2001 Effect of long-term administration of recombinant human growth hormone (rhGH) on plasma erythropoietin (EPO) and haemoglobin levels in anaemic patients with adult GH deficiency. Clinical Endocrinology 55 749-754.

Sohmiya M, Yamamoto H \& Kato Y 1993 Age and sex related changes in urinary growth hormone $(\mathrm{GH})$ levels in normal adults. Biomedical Research 4:227-238.

Sohmiya M, Ishikawa K \& Kato Y 1998 Stimulation of erythropoietin secretion by continuous subcutaneous infusion of recombinant human GH in anemic patients with chronic renal failure. European Journal of Endocrinology 138 302-306.

Ten Have SMTH, van der Lely AJ \& Lamberts SWJ 1997 Increase in haemoglobin concentrations in growth hormone deficient adults during human recombinant growth hormone replacement therapy. Clinical Endocrinology 47 565-570.
Tiong TS \& Herington AC 1991 Tissue distribution, characterization, and regulation of messenger ribonucleic acid for growth hormone receptor and serum binding protein in the rat. Endocrinology 129 $1628-1634$.

Udy GB, Towers RP, Snell RG, Wilkins RJ, Park SH, Ram PA, Waxman DJ \& Davey HW 1997 Requirement of STAT5b for sexual dimorphism of body growth rates and liver gene expression. PNAS 94 7239-7244.

Van Obberghen E 1944 Signalling through the insulin receptor and the insulin-like growth factor-I receptor. Diabetologia 37 S125-S134.

Watkinson G, McMenemey WH \& Evans G 1947 Hypopituitarism, hypogonadism, and anemia treated with testosterone. Lancet 252 631-634

Waynforth HB \& Flecknell PA 1992 In Experimental and Surgical Technique in the Rat, pp 316-322. San Diego: Academic Press.

Yamamoto H, Sohmiya M, Oka N \& Kato Y 1991 Effects of aging and sex on plasma insulin-like growth factor I (IGF-I) levels in normal adults. Acta Endocrinologica 124 497-500.

Zanjani ED, Foster J, Burlington H, Mann LJ \& Wasserman LR 1977 Liver as the primary site of erythropoietin formation in the fetus. Journal of Laboratory and Clinical Medicine 89 640-644.

Zanjani ED, Ascensao JL, McGlave PB, Banisadre M \& Ash RC 1981 Studies of the liver to kidney switch of erythropoietin production. Journal of Clinical Investigation 67 1183-1188.

Zhu T, Goh EL, Graichen R, Ling L \& Lobie PE 2001 Signal transduction via the growth hormone receptor. Cellular Signaling $\mathbf{1 3}$ 599-616.

Received 6 October 2004 Accepted 15 October 2004 